\title{
PREFACE
}

\section{Apraxia of Speech: From Concept to Clinic}

Speech and language pathologists embraced the notion of apraxia of speech as a clinical entity almost instantly and universally after Darley's recognition and description of it. Heightened enthusiasm and confidence in the clinical entity followed the experimental exploration of its nature and management by Darley and his protégés. Although clinically accepted, theoretical controversy over the term "apraxia"-its cognitive, linguistic, or neurological theoretical explanation; its diagnostic criteria; and its most effective treatment-has surrounded this category of motor speech disorder since its origin. Research on its nature and clinical management flourished in the 1970s and 1980s, but its popularity as a subject for study languished in 1990s. There has been, however, an almost feverish revival of interest in apraxia of speech within the past few years. With few exceptions, this interest has focused on various theoretical accounts for the disorder, and only a small handful of clinical researchers have continued to work tenaciously on addressing diagnostic and treatment issues. Although much is unknown about apraxia of speech, there is a great deal that is known that holds important implications for theory and clinical practice.

Therefore, when Dr. Helm-Estabrooks asked me to serve as Guest Editor for an issue of Seminars in Speech and Language on "apraxia of speech,” I readily accepted. My modest ob- jectives for the issue were to recruit those persons making primary contributions to the study of apraxia of speech and have them simply summarize what is known about apraxia of speech and present it in a form that is accurate and easily consumable by the student and the busy practicing clinician. I sought summaries about its neurological bases (Miller), its hypothesized psycholinguistic and motor mechanisms (Ziegler), the nature of the prosodic deficit in apraxia of speech (Boutsen and Christman), the contrast of adult acquired versus pediatric developmental apraxia of speech (Maassen), its definition and criteria for diagnosis (Croot), its assessment for treatment planning (Ballard and Robin), the research evidence supporting its efficacious treatment (Wambaugh), and specific advice about the selection of treatment targets (Odell). Selection of these authors has yielded an accessible and clinically relevant set of essays that meet and exceed my goals. What was expected about this set of manuscripts is that they would provide a state of the science summary about the nature, assessment, diagnosis, and treatment of apraxia of speech. This complex set of issues has been organized into a tractable set of variables that will guide the student, inform the practicing clinician, and eventually translate to better care for the person with apraxia of speech. What was unexpected about this set of manuscripts was that they would break important new the-

Apraxia of Speech: From Concept to Clinic. Editors in Chief, Nancy Helm-Estabrooks, Sc.D., and Nan Bernstein Ratner, Ed.D.; Guest Editor, Malcolm R. McNeil, Ph.D. Seminars in Speech and Language, volume 23, number 4, 2002. ${ }^{1}$ University of Pittsburgh, Pittsburgh, Pennsylvania. Copyright (C) 2002 by Thieme Medical Publishers, Inc., 333 Seventh Avenue, New York, NY 10001, USA. Tel: +1(212) 584-4662. 0734-0478,p;2002,23;04,221,222,ftx,en;ssl128b. 
oretical ground. They have done that by framing the all-important theoretical questions about the very nature of apraxia of speech and by connecting the theory with the clinical implications necessary to guide clinical practice.

The cognitive and clinical mechanisms and practices that underlie apraxia of speech are well-served by scientists and the scientific process. However, insight, passion, and devotion to understanding can also be found in philosophy and art. Vladimir Nabakov provides an insightful characterization of a neurogenic speech production problem that seizes the essence of apraxia of speech and captures the human consequences of this frequently devastating communication disorder. In his epic poem "Pale Fire," Nabakov tells the tale of Maud Shade, an 80-year-old woman who was suddenly silenced by an apparent stroke, moved to a sanitarium, and left to fade in the growing miasma of her life.

Maud Shade was eighty when a sudden hush fell on her life. We saw the angry flush and torsion of paralysis assail her noble cheek. We moved her to Pinedale, famed for its sanitarium. There she'd sit in the glassed sun and watch the fly that lit upon her dress and then upon her wrist. Her mind kept fading in the growing mist. She still could speak. She paused, and groped and found what seemed at first a serviceable sound, but from adjacent cells impostors took the place of words she needed, and her look spelt imploration as she sought in vain to reason with the monsters in her brain. (Nabakov, 1962)

Poets and clinicians are prized for their ability to apprehend what goes unnoticed by the untrained observer. The researcher is lauded for his or her ability to construct experiments that will isolate and manipulate a single variable in order to ascribe a predictable relationship between and among events. It has been the task of both clinician and researcher to describe, predict, and explain the relationships among central nervous system damage; speech; language; and emotional, intellectual, physical, and social behaviors consequent to that damage. The efforts that the authors of this issue of Seminars in Speech and Language have invested in their work are ultimately motivated by all the Maud Shades of the world. The Maud Shades of the world also motivate the countless hours of study, clinical preparation, and therapeutic implementation invested by the many caring clinicians that translate this theoretical and experimental work and bring it to the patients that these clinicians care about so genuinely. It is to all these devoted people that this work is dedicated.

\section{Malcolm R. McNeil, Ph.D.} Guest Editor ${ }^{1}$ 